Article

\title{
Improvement of Strength Parameters of Cement Matrix with the Addition of Siliceous Fly Ash by Using Nanometric C-S-H Seeds
}

\author{
Bartosz Szostak $^{1}$ (D) and Grzegorz Ludwik Golewski ${ }^{2, *(D)}$ \\ 1 Department of Conservation of Built Heritage, Faculty of Civil Engineering and Architecture, \\ Lublin University of Technology, Nadbystrzycka 40 str, 20-618 Lublin, Poland; b.szostak@pollub.pl \\ 2 Department of Structural Engineering, Faculty of Civil Engineering and Architecture, \\ Lublin University of Technology, Nadbystrzycka 40 str, 20-618 Lublin, Poland \\ * Correspondence: g.golewski@pollub.pl; Tel.: +48-81-538-43-94
}

Received: 16 November 2020; Accepted: 16 December 2020; Published: 21 December 2020

\begin{abstract}
Modification of a cement matrix using additives and admixtures has been a common practice for many years. The use of some mineral additives as substitutes for the cement, e.g., the siliceous fly ashes (FAs), has a positive effect on reducing the energy used in cement production. On the other hand, such activities may have negative effects due to the lowering of strength parameters of composites in early stages of curing. In order to solve this problem, over the last few years, thanks to the patented "seedings" technology, a branch of industry connected with the production of admixtures that accelerate the binding process has developed significantly. Therefore, the paper presents the results of research aimed at analyzing the parameters of FA cement matrix with the nanoadmixture containing the nanometric C-S-H seeds (nanoadmixture (NA)). By using the modern NA, an attempt was made to neutralize the negative influence of the used industrial waste on the structure of the cement matrix in the early stages of its curing. The paper presents the results of strength tests for the FA cement pastes modified by NA in seven test periods, i.e., after 8, 12, 24 and $72 \mathrm{~h}$, and 7, 14 and 28 days. Additionally, hydration heat tests were carried out on the analyzed material in the first 24 hours of curing.
\end{abstract}

Keywords: siliceous fly ash (FA); C-S-H seed; nanoadmixture (NA); concrete strength at early ages; cement matrix; compressive strength; tensile strength; hydration heat

\section{Introduction}

Modification of the concrete structure using fly ash (FA) has been a well-known procedure for almost 90 years [1]. Numerous works, e.g., [2-18], have confirmed a significant improvement in the mechanical properties and physical parameters of concrete, in which part of the cement has been replaced with this mineral additive or an additive composition in which one of the cement substitutes was FA-e.g., [19-23]. FA is an industrial waste, and its rational management is on the one hand problematic, and on the other hand rational and even desirable. The use of FA brings benefits manifesting in two ways-i.e.,:

- $\quad$ in an economic way (by reducing the content of expensive cement in the concrete), e.g., [24-26];

- from an ecological point of view (utilization of troublesome waste in the form of FA, reduction in energy consumption necessary to carry out the process of burning the Portland clinker, reduction in consumption of natural resources necessary to produce cement)—e.g., [27-29].

However, despite many advantages associated with the use of FA as a substitute for cement binders, such actions also have a negative impact on certain parameters of cement composites, which have 
undergone modifications of this type. In the studies [30-37], it was found that the FA addition significantly delays the hydration process of the paste and slows down the increase in concrete strength during the first days of curing. The rate of strength increase is a significant feature, as its reduction significantly limits the possibility of using the FA concretes in some branches of industry. Therefore, neutralization or reduction in this negative influence may significantly increase the scope of application of the FA concretes in the construction industry.

In order to improve strength properties at early ages, in concrete technology admixtures are commonly used to accelerate the setting time and hardening process-e.g., [38-43]. At the beginning of the second decade of the 21st century, a new type of such an admixture was proposed. The patented "seeding" technology consists of grafting the solution with synthetically produced crystals of calcium silicate hydrate. The grafting crystals do not require energy to nucleate, as is required in the case of ordinary cement hydration, and the existing nanocrystals only need to grow in saturated solution in the pores. In this way, the cement binder is set much faster. The use of such technology in FA concretes could significantly improve their early strength parameters and at the same time increase their possible range of application. It should be noted that so far only one paper on this topic has been published this year [44].

The application of nanotechnology containing the nanometric C-S-H seeds causes the beginning of the formation process of crystals of calcium silicate hydrate (C-S-H gel), which is tantamount to an increase in strength and hardness of the concrete [45-52]. This is particularly important in the production of concretes requiring such parameters in a relatively short time-e.g., in the prefabrication of concrete elements. Additionally, it allows the elimination of the effect of reduced early strength caused, among others, by FA addition. The nanometric C-S-H admixture has a colloidal form. It is made of countless fine C-S-H crystals with diameters of several nanometers. The nanocrystals are suspended in the liquid, which makes nanoadmixture (NA) liquid. Thanks to the liquid form and application of the nanometric seeds, their good distribution causes interaction with cement grains and accelerates the hydration process and structure development. Both the seeds and the hydration products thicken the nanostructure of the cement matrix to form a compact composite. These processes are shown schematically in Figure 1, while the SEM picture of the cement matrix microstructure after $4 \mathrm{~h}$ of maturing, after the NA application, is shown in Figure 2.

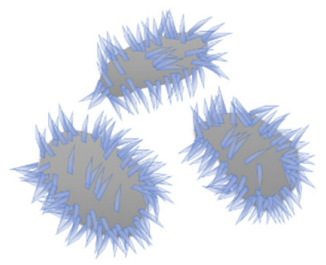

(a)

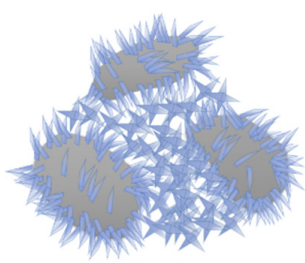

(b)

Figure 1. The formation of the C-S-H phase in the cement pastes: (a) without the nanoadmixture (NA); (b) using the NA with the C-S-H seeds.

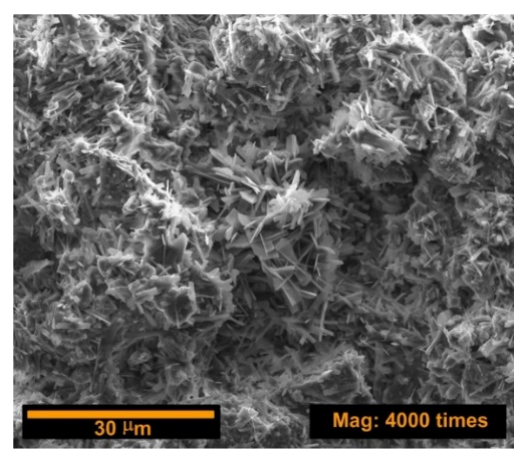

Figure 2. SEM picture of a cement matrix containing the C-S-H seeds after $4 \mathrm{~h}$ of curing. 
The NA containing hydrated calcium silicate seeds is an innovative method of accelerating the setting and hardening of a cement matrix. From an economic point of view, it is more expensive than currently used admixtures, with similar effects, by about two times. The main advantages of using it are:

- clearly no negative influence of the preparation on reinforcement in reinforced concrete structures;

- $\quad$ no adverse interaction with organic aggregates.

Many admixtures with similar effects, based mainly on chemical compounds such as calcium chloride, calcium nitrate, sodium nitrate, calcium formate, or sodium formate, can negatively affect the subsequent durability of cement composites. In the case of the NA, such effects have not been observed at this point.

The use of NA can also help to reduce the energy required for the concrete binding process and improve the earlier transport of prefabricated elements, as well as increase the speed of construction. The use of liquid NA, based on nanoparticles, provides options to modify and improve the early ages properties and strength of concrete [53].

The works [45-52] confirmed the validity of using NA for pastes based only on ordinary Portland cement (OPC). However, their effect has not been demonstrated in the case of composites with cement matrixes containing FA. Therefore, in the following paper, the effectiveness of NA application on the properties of cement matrix with the $20 \%$ FA addition was verified.

\section{Experimental Program}

\subsection{General Assumptions}

In order to determine the applicability and influence of NA on the parameters of the FA cement matrix, significant experimental studies were carried out on this type of material. During the experiments, the influence of the applied modification was checked:

- $\quad$ on the mechanical properties of the composite-e.g., [54-56];

- on the hydration heat, which is released during the matrix structure formation process-e.g., [57-59].

\subsection{Materials}

The tests were performed for two different mixtures modified with $20 \%$ addition of FA, one of which additionally contained $4 \%$ of NA (F20C4) and the other was treated as a reference (F20C0). The water-binder ratio $(\mathrm{w} / \mathrm{b})$ of the pastes tested was equal to 0.3 . The selection of the ratio was carried out experimentally. The amount of liquid components (water and NA) was selected in such a way that it was possible to disassemble the specimens after $8 \mathrm{~h}$ of curing. On the basis of the conducted experimental research, it was found that a higher $\mathrm{w} / \mathrm{b}$ ratio does not allow for earlier disassembly of the samples, while a lower ratio meant that not all the cement grains in the mixture were properly surrounded by water, which negatively affects their hydration. The composition of the samples of individual cement pastes is shown in Table 1.

Table 1. Components of the F20C0 and F20C4 mixtures $\left(\mathrm{kg} / \mathrm{m}^{3}\right)$.

\begin{tabular}{ccccc}
\hline Series Designation & OPC & FA & Water & NA-Master X-Seed 100 \\
\hline F20C0 & 1046 & 262 & 392 & - \\
F20C4 & 1046 & 262 & 340 & 52 \\
\hline
\end{tabular}

The NA used is a water suspension. Due to the reduction of an amount of water equal to the amount of the NA in modified mixtures, no significant influence of the NA on the consistency of the mixture was found. The consistency of both mixtures, tested with Vicat's apparatus, was the same. 
According to the classification included in the UNI-EN 197-1 manual, the cement used in the mixture was the Ordinary Portland Cement CEM I 32.5R. The chemical and phase compositions of the cement used in the tests are presented in Table 2.

Table 2. Chemical and phase composition of the CEM I 32.5R used in the research.

\begin{tabular}{ccc}
\hline Component & Content Expressed in (\% by Mass) & Share of Mineral Phases (\% by Mass) \\
\hline $\mathrm{SiO}_{2}$ & $15.00 \%$ & $\mathrm{C} 3 \mathrm{~S}-61.0 \%$ \\
$\mathrm{Al}_{2} \mathrm{O}_{3}$ & $2.78 \%$ & $\mathrm{C} 2 \mathrm{~S}-12.5 \%$ \\
$\mathrm{Fe}_{2} \mathrm{O}_{3}$ & $2.72 \%$ & $\mathrm{C} 3 \mathrm{~A}-8.6 \%$ \\
$\mathrm{CaO}$ & $71.06 \%$ & $\mathrm{C} 4 \mathrm{AF}-4.3 \%$ \\
$\mathrm{MgO}$ & $1.38 \%$ & - \\
$\mathrm{SO}_{3}$ & $4.56 \%$ & - \\
$\mathrm{K}_{2} \mathrm{O}$ & $1.213 \%$ & - \\
$\mathrm{Cl}$ & $0.08 \%$ & - \\
Insoluble Residue & $1.27 \%$ & - \\
Loss of Roasting & $3.64 \%$ & - \\
\hline
\end{tabular}

The composition of the fly ash included in the mixture is shown in Table 3. In accordance with the generally accepted classification contained in the ASTM 618-03, the fly ash is classified as the F class. However, according to the UNI-EN 450-1 instruction, the ash is of the $N$ class.

Table 3. Chemical composition of the fly ashes.

\begin{tabular}{|c|c|c|c|c|c|c|c|c|c|c|c|c|c|}
\hline Component & $\mathrm{SiO}_{2}$ & $\mathrm{Al}_{2} \mathrm{O}_{3}$ & $\mathrm{Fe}_{2} \mathrm{O}_{3}$ & $\mathrm{~K}_{2} \mathrm{O}$ & $\mathrm{SO}_{3}$ & $\mathrm{MgO}$ & $\mathrm{CaO}$ & $\mathrm{P}_{2} \mathrm{O}_{5}$ & $\mathrm{Ag}_{2} \mathrm{O}$ & $\mathrm{BaO}$ & $\mathrm{TiO}_{2}$ & $\mathrm{SrO}$ & LOI \\
\hline \multirow[t]{2}{*}{$\begin{array}{c}\text { Content } \\
{[\% \text { by mass] }}\end{array}$} & 55.27 & 26.72 & 6.66 & 3.01 & 0.47 & 0.81 & 2.35 & 1.92 & 0.10 & 0.10 & 1.89 & 0.22 & 4.66 \\
\hline & \multicolumn{12}{|c|}{$\mathrm{SiO}_{2}+\mathrm{Al}_{2} \mathrm{O}_{3}+\mathrm{Fe}_{2} \mathrm{O}_{3}=88.65 \geq 70.00 \%$} & \\
\hline
\end{tabular}

Additionally, Table 4 presents a division into the fraction of siliceous fly ash used.

Table 4. Division of the fly ash into fractions.

\begin{tabular}{cc}
\hline Particle Size $(\mu \mathrm{m})$ & \% Volume \\
\hline $0.01-2$ & 1.12 \\
$2-20$ & 23.72 \\
$20-50$ & 20 \\
$50-100$ & 21.59 \\
$100-250$ & 25.49 \\
$250-500$ & 5.99 \\
$500-1000$ & 1.09 \\
$1000-2000$ & 0.93 \\
\hline
\end{tabular}

All samples were made as beams suitable for the cement paste testing. Their dimensions were $40 \times 40 \times 160 \mathrm{~mm}$ (Figure 3a). The mixture was placed in the tripartite steel forms, in two layers. The layers were successively compacted using a standardized laboratory shaker according to the EN 196-1 [60]. The samples were stored under constant conditions in a climate chamber, in a temperature of $20^{\circ} \mathrm{C}$ and $90 \%$ relative humidity. The samples were stored under similar thermo-humidity conditions throughout the entire curing process, until the time of testing. 


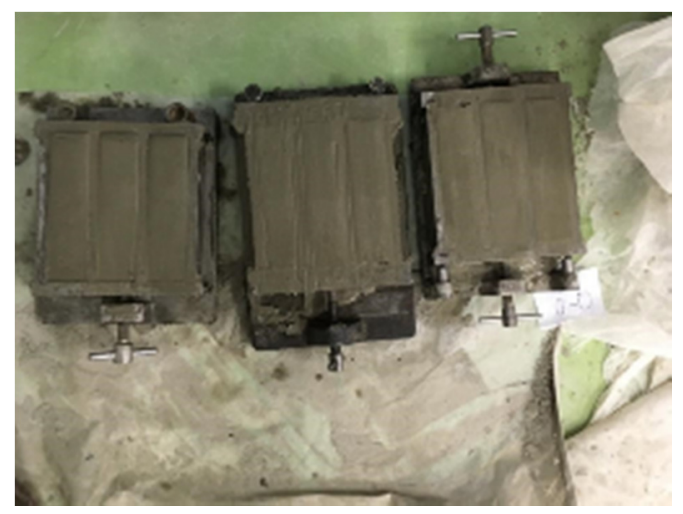

(a)

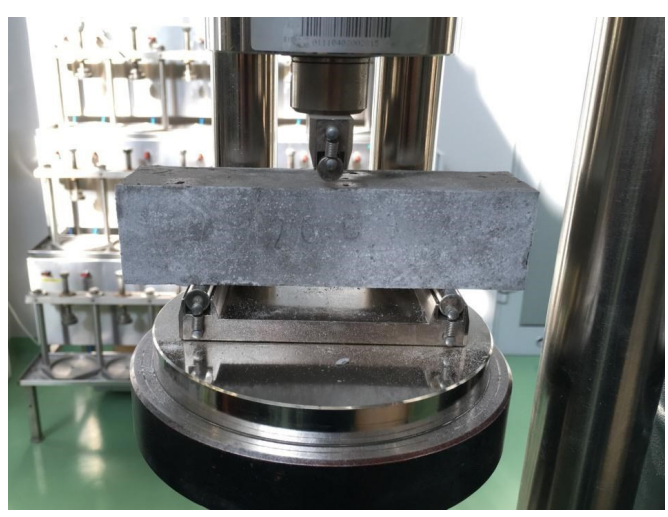

(b)

Figure 3. The cement paste samples: (a) after being placed in molds; (b) during strength tests.

\subsection{Scope of the Experiments}

In order to determine the effect of the modifiers used (in the form of FA and NA containing C-S-H phase seeds) on selected properties of the cement pastes, the following tests were conducted:

- the compressive strength- $f_{\mathrm{c}}$;

- the tensile strength- $f_{\mathrm{cf}}$;

- the hydration heat.

\subsection{Testing Procedures}

\subsubsection{Tensile and Compressive Strength Tests}

The tensile and compressive strength tests $\left(f_{\mathrm{c}}, f_{\mathrm{cf}}\right)$ were carried out according to the EN 196-1 [60]. For each series and test period, 3 specimens were prepared. The tests were carried out over 7 test periods: after $8,12,24,48$ and $72 \mathrm{~h}$, and 14 and 28 days. During the test, the samples were positioned in such a way that the compacting surface was perpendicular to the applied load. The test was carried out on the Advantest 9 strength machine by controls using a special apparatus for testing strength properties (Figure 3b).

The tensile strength of each specimen was determined from the following formula according to [60].

$$
f_{c f}=\frac{3 \cdot F \cdot l}{2 \cdot d_{1} \cdot d_{2}}
$$

where:

$f_{c f}$-tensile strength $(\mathrm{MPa})$;

$F$-destructive force $(N)$;

l-spacing of supports ( $\mathrm{mm})$;

$d_{1}, d_{2}$ - dimensions of the sample (width and height) (mm).

Compressive strength of each series was determined on the basis of the formula according to [60].

$$
f_{c}=\frac{F}{A_{c}}
$$

where:

$f_{c}$-compressive strength (MPa);

$F$-destructive force $(N)$;

$A_{c}$ 一the surface area of the sample to be tested-40 $\times 40 \mathrm{~mm}\left(\mathrm{~mm}^{2}\right)$. 


\subsubsection{Hydration Heat Test}

The tests were performed in a non-adiabatic-isothermal differential microcalorimeter (BMR). In order to carry out the test, a $5 \mathrm{~g}$ sample was placed in a measuring cylinder. After stabilizing the parameters of the apparatus, water was introduced into the cylinders so that the $\mathrm{w} / \mathrm{b}$ ratio of 0.3 was maintained.

The total thermal effect $Q(t)$ was determined from the formula:

$$
\frac{1}{\alpha} d Q(t)=\tau d \theta(t)+\theta(t) d t
$$

However, the separated thermal power was calculated:

$$
\frac{1}{\alpha} \frac{d Q}{d t}(t)=\tau \frac{d \theta(t)}{d t}+\theta(t) d t
$$

where:

$\theta(t)$-thermoelectric power of semiconductor thermoelectric cells of the microcalorimeter;

$\alpha, \tau$-appropriate heat transfer coefficients and the calorimeter time constant determined in the reference measurement.

\section{Results and Discussion}

\subsection{Strength Tests Results}

The compressive strengths of the tested pastes after $8 \mathrm{~h}$ of curing were more than four times higher in NA modified samples. The increase in strength was visible not only during the test, but even empirically during the disassembly of samples. Modified samples were much harder and the cement paste appeared to be more concentrated. After $12 \mathrm{~h}$ of testing, the strength of modified samples was much more than two times higher. After the first $24 \mathrm{~h}$ of curing, the increase in strength after the NA application was still clear and more than 1.5 times larger. After $72 \mathrm{~h}$ of curing, until day 28 , no positive or negative effects of the applied NA were noted. Its effect during this period can be described as completely neutral. After 7, 14 and 28 days, the compressive strength values were practically the same, regardless of the applied modification.

The results of strength tests are shown in Figures 4 and 5. The strength values are average values from the tests. In addition, the figures contain bars showing the spread of results for each series.

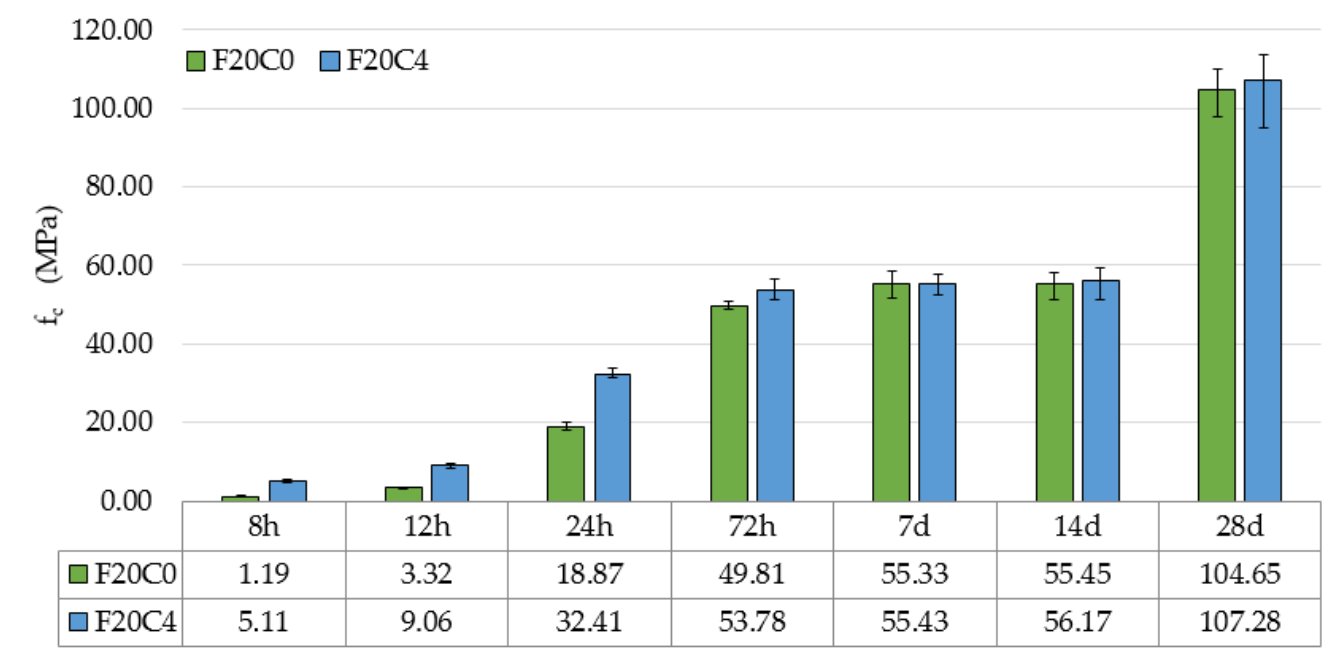

Figure 4. Results showing cement pastes' compressive strengths. 


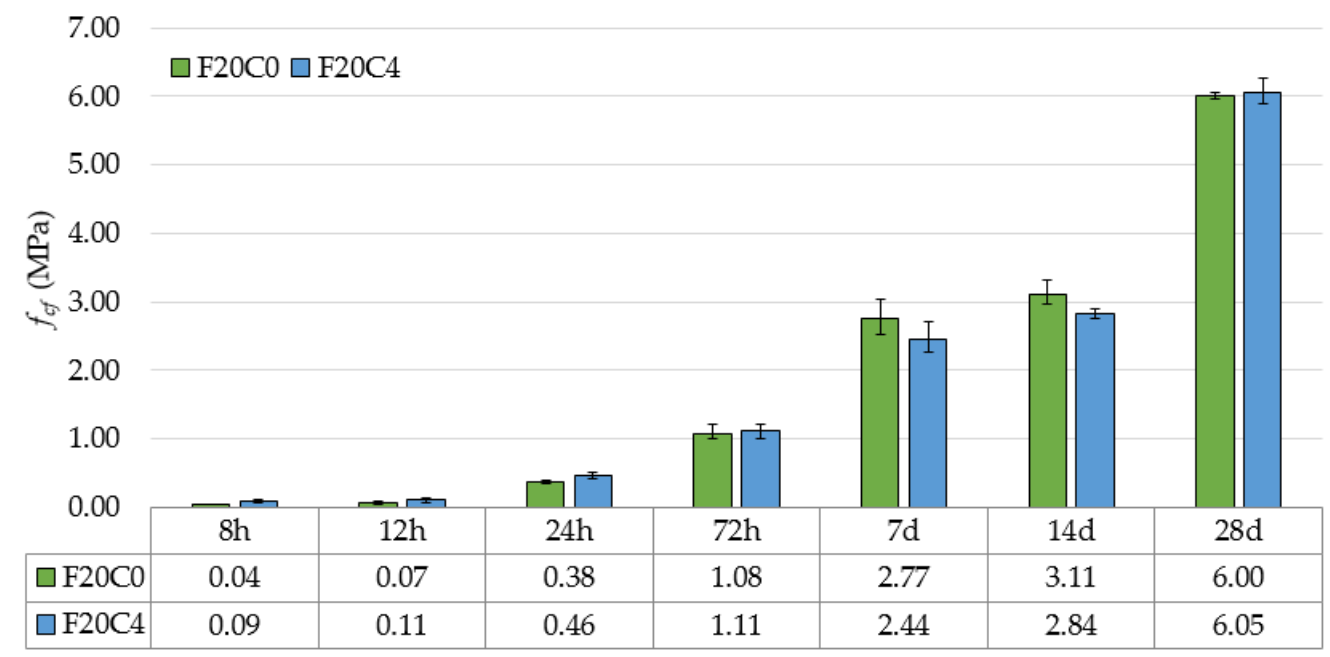

Figure 5. Results showing the tensile strengths of the cement pastes.

Table 5 presents detailed results including the standard deviation " $\mathrm{s}$ ", percentage coefficient of variation " $v$ " and maximum and minimum strengths from the test. The average value of six samples is presented as $\mathrm{f}_{\mathrm{c}}$.

Table 5. Detailed results for the compressive strength test.

\begin{tabular}{ccccccc}
\hline Sample Designation & Test Period & $f_{c}$ & $s$ & $V$ & $f_{c, \text { max }}$ & $f_{c, \text { min }}$ \\
\hline F20C0 & $8 \mathrm{~h}$ & 1.19 & 0.07 & $5.81 \%$ & 1.26 & 1.06 \\
F20C4 & $8 \mathrm{~h}$ & 5.11 & 0.17 & $3.25 \%$ & 5.33 & 4.89 \\
F20C0 & $12 \mathrm{~h}$ & 3.32 & 0.12 & $3.62 \%$ & 3.50 & 3.13 \\
F20C4 & $12 \mathrm{~h}$ & 9.06 & 0.45 & $4.95 \%$ & 9.68 & 8.38 \\
F20C0 & $24 \mathrm{~h}$ & 18.87 & 0.73 & $3.87 \%$ & 20.07 & 18.01 \\
F20C4 & $24 \mathrm{~h}$ & 32.41 & 0.82 & $2.52 \%$ & 33.72 & 31.36 \\
F20C0 & $72 \mathrm{~h}$ & 49.81 & 0.93 & $1.87 \%$ & 50.98 & 48.84 \\
F20C4 & $72 \mathrm{~h}$ & 53.78 & 2.10 & $3.91 \%$ & 56.35 & 51.31 \\
F20C0 & $7 \mathrm{~d}$ & 55.33 & 2.28 & $4.13 \%$ & 58.59 & 51.59 \\
F20C4 & $7 \mathrm{~d}$ & 55.43 & 1.97 & $3.55 \%$ & 57.91 & 52.68 \\
F20C0 & $14 \mathrm{~d}$ & 55.45 & 2.10 & $3.78 \%$ & 58.01 & 51.32 \\
F20C4 & $14 \mathrm{~d}$ & 56.17 & 2.79 & $4.97 \%$ & 59.25 & 51.34 \\
F20C0 & $28 \mathrm{~d}$ & 104.65 & 3.56 & $3.40 \%$ & 109.91 & 97.88 \\
F20C4 & $28 \mathrm{~d}$ & 107.28 & 5.76 & $5.37 \%$ & 113.59 & 95.13 \\
\hline
\end{tabular}

In the case of tensile strength, an increase in strength after the NA application was also noted. However, this increase was smaller than in the case of compressive strength. After the first $8 \mathrm{~h}$ of curing, the strength was more than two times higher, after $12 \mathrm{~h}$ it was 1.5 times higher, after $24 \mathrm{~h}$ it was more than 1.0 times higher, while after 3 days the values of tensile strength from both the NA modified and reference samples were similar. In the case of the tensile strength between 3 and 28 day of curing, lower strength of the NA modified samples was observed. This may be related to building the structure in large quantities between OPC and FA grains. Relative increases in the analyzed strength in the paste containing NA compared to the reference paste are summarized in Figure 6. 


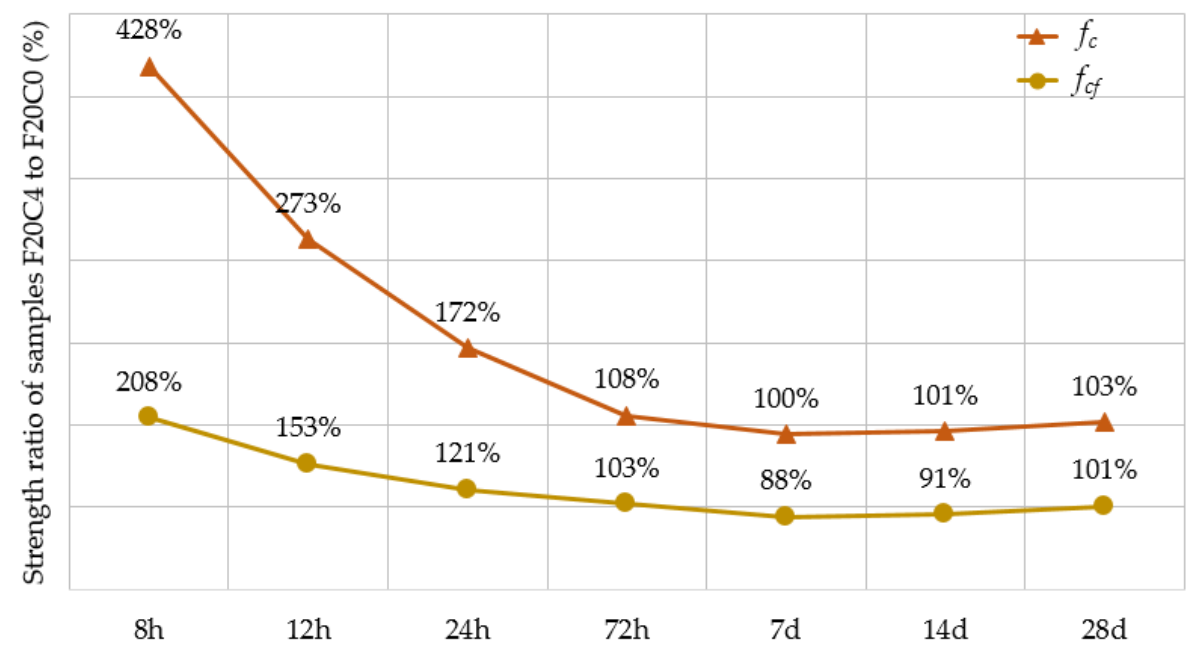

Figure 6. Increase in the compressive strength $\left(f_{c}\right)$ and tensile strength $\left(f_{c f}\right)$ of the NA modified paste compared to the reference one.

Table 6 presents detailed results including the standard deviation " $\mathrm{s}$ ", percentage coefficient of variation " $v$ " and maximum and minimum strengths from the test. As $\mathrm{f}_{\mathrm{cf}}$, the average value of three samples is presented.

Table 6. Detailed results for the bending tensile strength test.

\begin{tabular}{ccccccc}
\hline Sample Designation & Test Period & $f_{c f}$ & $s$ & $V$ & $f_{c f, \text { max }}$ & $f_{c f, \text { min }}$ \\
\hline FA20C0 & $8 \mathrm{~h}$ & 0.04 & 0.00 & $3.98 \%$ & 0.04 & 0.04 \\
FA20C4 & $8 \mathrm{~h}$ & 0.09 & 0.02 & $20.44 \%$ & 0.11 & 0.07 \\
FA20C0 & $12 \mathrm{~h}$ & 0.07 & 0.02 & $22.26 \%$ & 0.08 & 0.05 \\
FA20C4 & $12 \mathrm{~h}$ & 0.11 & 0.03 & $25.74 \%$ & 0.14 & 0.08 \\
FA20C0 & $24 \mathrm{~h}$ & 0.38 & 0.02 & $5.40 \%$ & 0.40 & 0.35 \\
FA20C4 & $24 \mathrm{~h}$ & 0.46 & 0.04 & $9.00 \%$ & 0.51 & 0.41 \\
FA20C0 & $72 \mathrm{~h}$ & 1.08 & 0.10 & $9.24 \%$ & 1.22 & 1.00 \\
FA20C4 & $72 \mathrm{~h}$ & 1.11 & 0.09 & $8.34 \%$ & 1.22 & 1.00 \\
FA20C0 & $7 \mathrm{~d}$ & 2.77 & 0.21 & $7.57 \%$ & 3.04 & 2.53 \\
FA20C4 & $7 \mathrm{~d}$ & 2.44 & 0.19 & $7.71 \%$ & 2.70 & 2.27 \\
FA20C0 & $14 \mathrm{~d}$ & 3.11 & 0.15 & $4.73 \%$ & 3.31 & 2.97 \\
FA20C4 & $14 \mathrm{~d}$ & 2.84 & 0.06 & $2.04 \%$ & 2.89 & 2.76 \\
FA20C0 & $28 \mathrm{~d}$ & 6.00 & 0.03 & $0.54 \%$ & 6.05 & 5.96 \\
FA20C4 & $28 \mathrm{~d}$ & 6.05 & 0.15 & $2.53 \%$ & 6.25 & 5.89 \\
\hline
\end{tabular}

\subsection{Hydration Heat Test Results}

The amount of heat released in time depends on the reactions occurring during the cement matrix setting. The main transformations that occur are the hydration of subsequent clinker phases. Due to the hydration reactions and additional pozzolanic reactions resulting from the use of FA, the amount of heat released over time increases. Figure 7 shows the results of hydration heat tests. 


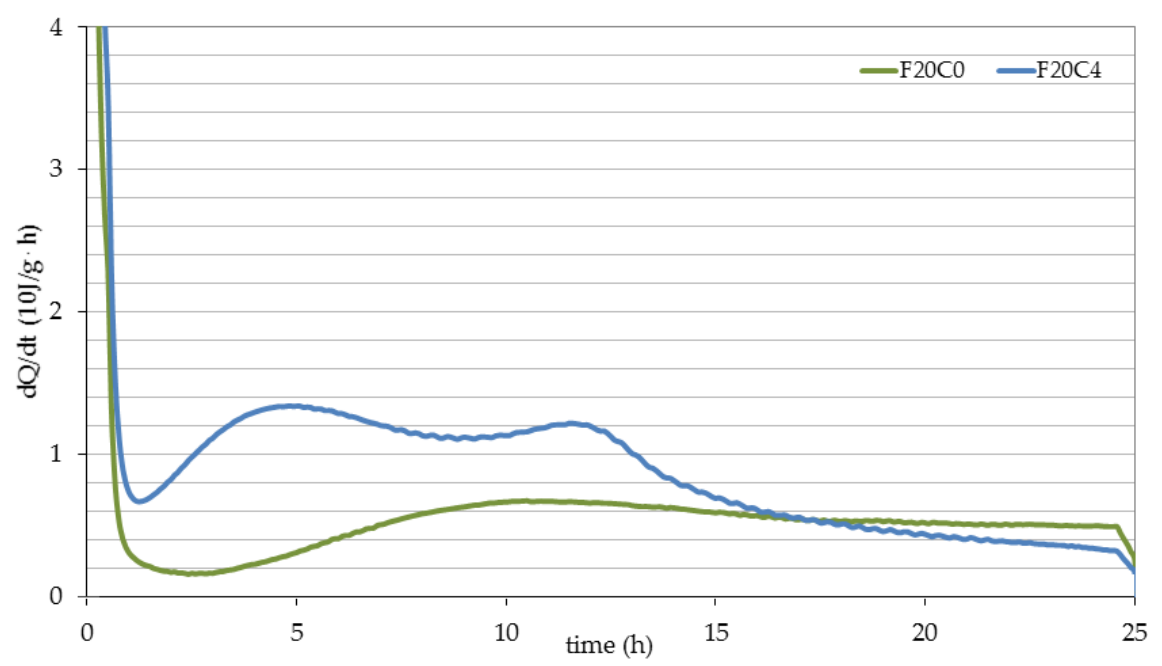

Figure 7. The amount of heat released during the curing of cement pastes.

The experiments were conducted for the first $24 \mathrm{~h}$ of curing of the analyzed pastes. A clear increase in the amount of heat released in all tested samples was observed at a similar time as the beginning of their setting time after $270 \mathrm{~min}$ for F20C0 and about $170 \mathrm{~min}$ for the F20C4 series.

The highest amount of heat was emitted during the hydration reaction of tricalcium aluminate (C3A)—nearly $900 \mathrm{~J} / \mathrm{g}$. However, this reaction was slowed down by setting time controllers (e.g., gypsum) and conversion of $\mathrm{C} 3 \mathrm{~A}$ into ettringite. As a result of this, first of all, there is hydration of alite (C3S) and then of belite (C2S). Hydration of C3S and C2S is mainly responsible for the hardening and setting of the cement matrix as well as for the mechanical strength at early ages.

A significant increase in the amount of hydration heat released was observed after the NA modification of the cement matrix. It resulted in a nearly five-fold increase in the amount of heat released after $4 \mathrm{~h}$ (Figure 7). This means that, both in the cement grains space and in the free space (which was helped by the use of NA), the reaction and formation of crystalline phases, including mainly siliceous gel, occurred. The use of NA allowed for a more efficient use of both the cement itself and additionally the use of free spaces between the grains to create a compact and resistant structure of the cement matrix. A much greater amount of the heat released, in the NA modified samples, was visible during the first 16 hours of mixture curing. The increase in strength during this period is also confirmed by the strength tests of the pastes (Figures 4 and 5).

In the case of NA modified samples, the figures of the heat released over time have, in addition to changes in values, also changed in terms of the characteristic setting course. According to the commonly known models of cement matrix setting and hardening, the beginning of the setting time is accompanied by rapid heat emission. Then, after reaching the peak value, after a few hours of testing (usually 6-10 h), the amount of heat released decreases and has a decreasing tendency to the end of the experiment. The NA application caused the hydration heat release function to be atypical.

Figure 8 shows the ratio of the amount of hydration heat released over time for the F20C4 samples to the results obtained for the F20C0. There is a significant increase in the amount of heat released during the first hours of curing. After $4 \mathrm{~h}$ of curing, for the NA samples, the amount of heat was almost six times higher. This is due to the formation of the cement matrix structure. In case of a matrix based only on cement and FA, hydration occurs on cement grains. The hydration products in the form of C-S-H gel expand over time towards the free spaces filling the matrix structure. 


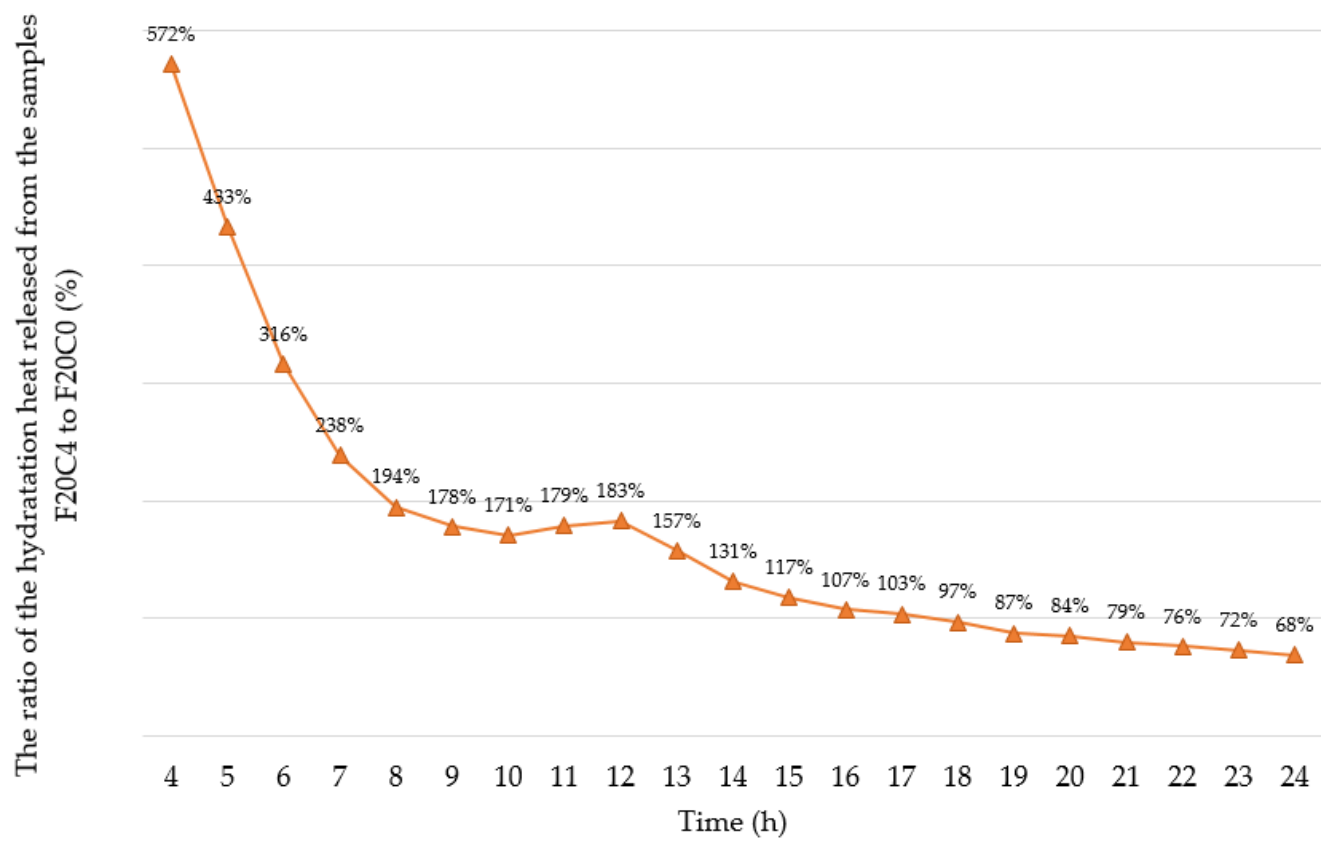

Figure 8. Increase in the amount of heat released from the NA modified paste compared to the reference one.

After the NA application, the calcium silicate hydrate was produced much faster. There was a rapid increase in the amount of heat released with the beginning of the setting time. After $6 \mathrm{~h}$, this value began to decrease rapidly, but after $10 \mathrm{~h}$ of curing, another increase in the amount of heat released was observed, which is rather unusual in the case of a traditional cement matrix setting process. The structure of FA20C0 and FA20C4 after $8 \mathrm{~h}$ is shown in Figure 9. On the basis of the SEM images, more hydration products (crystallized) in the FA20C4 series can be seen. The is confirmed by the SEM-EDS analysis. The ratio of compounds containing a lime (C) to compounds containing a silica (S) was compared. Smaller C/S ratio indicates the formation of more hydration products and, connected with it, more matrix filling. In the case of NA modified samples, after $12 \mathrm{~h}$ the ratio was 1.3, while in the case of FA20C0 samples it was 2.9. A significantly lower C/S ratio in FA20C4 samples indicates the formation of more hydration products. The use of NA may therefore also have a positive effect on the reduction in porosity of cement composites.

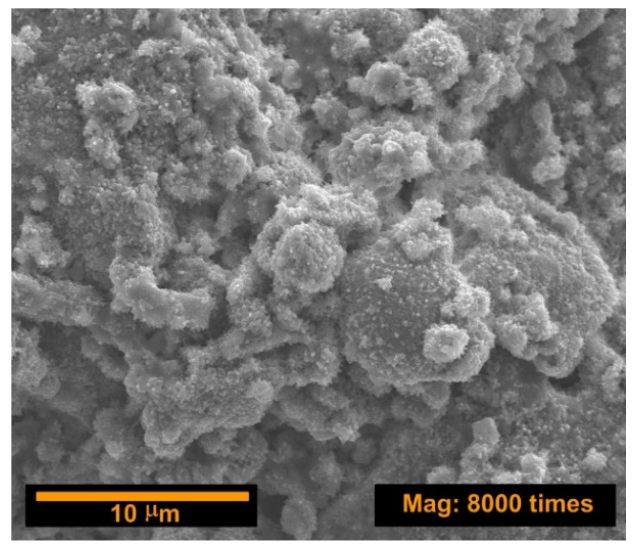

(a)

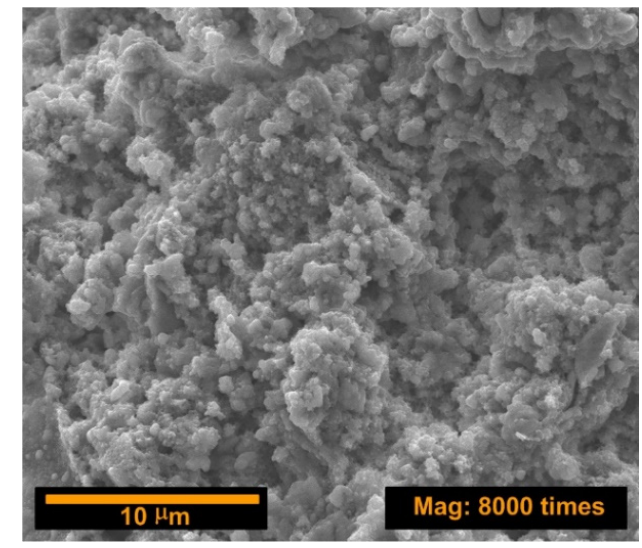

(b)

Figure 9. SEM picture of a cement matrix after $8 \mathrm{~h}$ of curing: (a) without the C-S-H seeds; (b) containing the C-S-H seeds. 
At the same time, the hydration products appear both on cement grain surfaces and in the voids. The formation of a significant amount of hydration products is associated with an increase in the amount of heat released during this time. The increased amount of heat released indicates the formation of more siliceous gel responsible for binding and setting the structure of the cement matrix. Additionally, the C-S-H gel has a significant impact on the strength increase, which was confirmed by the previously described tests of mechanical parameters (Figures 4 and 5).

The second heat gain is at the level of $180 \%$ and was observed after $12 \mathrm{~h}$ of curing (Figure 8). This is probably due to the rehydration of OPC clinker phases, the formation of monosulphate and the hydration reaction of tricalcium aluminate. In order for the reaction to take place, it is necessary to have an appropriate concentration of sulfates and the presence of portlandite $\mathrm{Ca}(\mathrm{OH})_{2}$ formed in the $\mathrm{C} 3 \mathrm{~S}$ hydration reaction. In [61], it is shown that for the complete over-reaction of C3A in Portland cement, an appropriate concentration of sulfur compounds is needed. After exhaustion of the reaction with gypsum, the tricalcium aluminate is rapidly hydrated and ettringite (AFt) becomes a monosulphate (AMf). The C3A hydration reaction is a very exothermic reaction (about $900 \mathrm{~J} / \mathrm{g}$ ) and may increase the amount of heat released. Increased heat also increases the binding temperature, which accelerates the AFt to AMf reaction. In case of mixtures not modified with admixtures accelerating the setting time, the C3A hydration is possible only after $48 \mathrm{~h}$ of maturation and is less intense. Due to the NA application, as a result of the synthesis, the hydration reaction of $\mathrm{C} 3 \mathrm{~S}, \mathrm{Ca}(\mathrm{OH})_{2}$ formation and gypsum over-reaction was accelerated. Due to these factors, it was possible to hydrate the tricalcium aluminate earlier, as can be seen in the graph in Figure 7, between 10 and 15 hours, for the FA20C4 series.

After $16 \mathrm{~h}$ of testing, the amount of heat released, both for FA samples and without this additive, was lower for the NA modification. An increased amount of heat released during maturation may adversely affect the value of the rheological contraction. However, the studies presented in [62] confirm the lack of such an effect when using the NA. During the whole maturation period (from 1 to 90 days), in samples modified with FA and admixture, a lower shrinkage value was observed compared to samples without NA. This may be related to a higher amount of heat released during the first hours of hydration and its decrease in later periods (after $16 \mathrm{~h}$ ), which is confirmed by the results of the heat release ratio test for the compared samples (Figure 9). On the basis of the conducted tests, it was found that the NA has a positive influence on the value of shrinkage associated with drying.

\section{Summary and Conclusions}

The use of NA, containing active seeds of the C-S-H phase, significantly improves the strength parameters of the cement matrix during the first hours of curing. The clearest influence was noted in the first $24 \mathrm{~h}$. After $8 \mathrm{~h}$, the increase in compressive strength was more than four-fold, and the tensile strength was more than two-fold. With time, the influence of the applied nanoadmixture decreased. After $24 \mathrm{~h}$, it was almost imperceptible. No positive or negative influence of the NA application on subsequent test periods was noted. Between 7 and 28 days after the pastes were made, the compressive and tensile strength parameters for the NA and reference cement paste were very similar. Additionally, no negative influence of the NA application on the percentage coefficient of variation and standard deviation of results was found.

On the basis of the hydration heat test, much larger amounts of heat were found in the case of the NA modified cement matrix. After $4 \mathrm{~h}$, the amount of heat released was more than five times higher than in the case of the reference sample. The use of NA also led to the earlier hydration of subsequent cement products (C3A), which may have a beneficial effect on the filling of the composite structure and reducing its porosity. During the test, an unusual course of the heat emission function was also observed. This shows a faster hydration of subsequent phases and more efficient structure development in the case of the NA matrix. Since, as shown in the paper, the use of NA in the case of FA cement matrix is possible, and its influence on the strength parameters is clear, in the future, further in-depth research on these modern materials will be undertaken. Due to the much higher amount of the hydration heat released, further research will be conducted on shrinkage of the matrix 
during the first hours of curing. Linking the hydration heat to the evaluation of cement matrix shrinkage would allow us to determine whether the earlier intensification of exothermic reactions, caused by the presence of NA, can positively affect the matrix structure due to the postponement of the beginning of matrix shrinkage- e.g., [63].

On the basis of the conducted research, the increase in mechanical strength of modified cement-ash composites was confirmed. Due to the significant improvement of strength parameters during the first hours of maturation, the composite can be successfully used where fast concrete setting is important. The advantages resulting from the use of "seeding" technology can be used for material modification in the following areas of the construction industry:

in the concrete prefabrication technology;

in concretes used in active repairs;

in sprayed concretes;

in a modern technology of printing buildings in 3D.

Additionally, due to the increased amount of heat released during the first hours of maturation, the NA can also be used in concretes, which matures at low temperatures. However, this concept should be confirmed by additional tests.

Additionally, it is planned to assess the phase composition of the pastes using XRF and SEM-EDS methods. Analyses of this type would allow us to determine the degree of hydration of individual reaction products, which occur during the formation of the modified cement paste structure-e.g., [64].

Furthermore, in the field of macroscopic research, it is expected that, in the future, an analysis of the work of concrete structural elements containing the FA-NA modification in the composition of the cement matrix will be carried out using a modern digital image correlation (DIC) technique-e.g., [65,66].

Author Contributions: B.S. conducted experiments, collected the test results and wrote the manuscript. G.L.G. took part in the interpretation of the results and supervision. All authors have read and agreed to the published version of the manuscript.

Funding: This research received no external funding

Acknowledgments: This work was financially supported by Ministry of Science and Higher Education within the statutory research number FN15/ILT/2020.

Conflicts of Interest: The authors declare no conflict of interest.

\section{References}

1. Giergiczny, Z. Fly ash and slag. Cem. Concr. Res. 2019, 124, 105826. [CrossRef]

2. Golewski, G.L.; Sadowski, T. A study of mode III fracture toughness in young and mature concrete with fly ash additive. Solid State Phenom. 2016, 254, 120-125. [CrossRef]

3. Golewski, G.L. Studies of natural radioactivity of concrete with siliceous fly ash addition. Cem. Wapno Beton 2015, 2, 106-114.

4. Zhang, P.; Gao, Z.; Wang, J.; Guo, J.; Hu, S.; Ling, Y. Properties of fresh and hardened fly ash/slag based geopolymer concrete: A review. J. Clean. Prod. 2020, 270, 122389. [CrossRef]

5. Zhang, R.; Guo, F.; Xia, Y.; Tan, J.; Xing, Y.; Gui, X. Recovering unburned carbon from gasification fly ash using saline water. Waste Manag. 2019, 98, 29-36. [CrossRef]

6. Bicer, A. Effect of production temperature on thermal and mechanical properties of polystyrene-fly ash composites. Adv. Compos. Lett. 2020, 29, 1-8. [CrossRef]

7. Kovacik, J.; Marsavina, L.; Linul, E. Poisson's ratio of closed-cell aluminum foams. Materials 2018, 11, 1904. [CrossRef]

8. Golewski, G.L. A novel specific requirements for materials used in reinforced concrete composites subjected to dynamic loads. Compos. Struct. 2019, 223, 110939. [CrossRef]

9. Golewski, G.L. A new principles for implementation and operation of foundations for machines: A review of recent advances. Struct. Eng. Mech. 2019, 71, 317-327. 
10. Raheel, M.; Rahman, F.; Ali, Q. A stoichiometric approach to find optimum amount of fly ash needed in cement concrete. SN Appl. Sci. 2020, 2, 1100. [CrossRef]

11. Chindaprasirt, P.; Rukzon, S. Strength, porosity and corrosion resistance of ternary blend Portland cement, rice husk ash and fly ash mortar. Constr. Build. Mater. 2008, 22, 1601-1606. [CrossRef]

12. Candamano, S.; Crea, F.; Iorfida, A. Mechanical characterization of basalt fabric-reinforced alkali-activated matrix composite: A preliminary investigation. Appl. Sci. 2020, 10, 2865. [CrossRef]

13. Zhang, P.; Han, S.; Golewski, G.L.; Wang, X. Nanoparticle-reinforced building materials with applications in civil engineering. Adv. Mech. Eng. 2020, 12, 1-4. [CrossRef]

14. Cai, X.; He, Z.; Tang, S.; Chen, X. Abrasion erosion characteristics of concrete made with moderate heat Portland cement, fly ash and siliceous fume using sandblasting test. Constr. Build. Mater. 2016, 127, 804-814. [CrossRef]

15. Golewski, G.L. Changes in the fracture toughness under mode II loading of low calcium fly ash (LCFA) concrete depending on ages. Materials 2020, 13, 5241. [CrossRef] [PubMed]

16. Golewski, G.L. Determination of fracture toughness in concretes containing siliceous fly ash during mode III loading. Struct. Eng. Mech. 2017, 62, 1-9. [CrossRef]

17. Hu, X.; Shi, C.; Shi, Z.; Tong, B.; Wang, D. Early age shrinkage and heat of hydration of cement-fly ash-slag ternary blends. Constr. Build. Mater. 2017, 153, 857-865. [CrossRef]

18. Joshaghani, A. The effect of trass and fly ash in minimizing alkali-carbonate reaction in concrete. Constr. Build. Mater. 2017, 150, 583-590. [CrossRef]

19. Golewski, G.; Sadowski, T. Fracture toughness at shear (mode II) of concretes made of natural and broken aggregates. Brittle Matrix Compos. 2006, 8, 537-546.

20. Bandura, L.; Panek, R.; Madej, J.; Franus, W. Synthesis of zeolite-carbon composites using high-carbon fly ash and their adsorption abilities towards petroleum substances. Fuel 2021, 283, 119173. [CrossRef]

21. Szcześniak, A.; Zychowicz, J.; Stolarski, A. Influence of fly ash additive on the properties of concrete with slag cement. Materials 2020, 13, 3265. [CrossRef] [PubMed]

22. Gil, D.M.; Golewski, G.L. Potential of siliceous fly ash and silica fume as a substitute of binder in cementitious concrete. E3S Web Conf. 2018, 49, 00030. [CrossRef]

23. Gil, D.M.; Golewski, G.L. Effect of silica fume and siliceous fly ash addition on the fracture toughness of plain concrete in mode I. IOP Conf. Ser. Mater. Sci. Eng. 2018, 416, 012065. [CrossRef]

24. Golewski, G.L. The influence of microcrack width on the mechanical parameters in concrete with the addition of fly ash: Consideration of technological and economical benefits. Constr. Build. Mater. 2019, 197, 849-861. [CrossRef]

25. Suchorab, Z.; Franus, M.; Barnat-Hunek, D. Properties of fibrous concrete made with plastic fibers from E-Waste. Materials 2020, 13, 2414. [CrossRef]

26. Gastaldini, A.L.G.; Isaia, G.C.; Saciloto, A.P.; Missau, F.; Hoppe, T.F. Influence of curing time on the chloride resistance of concrete containing rice husk ash: A technical and economical feasibility study. Cem. Concr. Compos. 2010, 32, 783-793. [CrossRef]

27. Golewski, G.L. Energy savings associated with the use of fly ash and nanoadditives in the cement composition. Energies 2020, 13, 2184. [CrossRef]

28. Ye, J.; Zubair, M.; Wang, S.; Cai, Y.; Zhang, P. Power production waste. Water Environ. Res. 2019, 91, 858-868. [CrossRef]

29. Chalangaran, N.; Farzampour, A.; Paslar, N. Nano silica and metakaolin effects on the behaviour of concrete containing rubber crumbs. Civ. Eng. 2020, 1, 264-274.

30. Golewski, G.L.; Sadowski, T. The fracture toughness the $\mathrm{K}_{\mathrm{IIIc}}$ of concretes with fly ash (FA) additive. Constr. Build. Mater. 2017, 143, 444-454. [CrossRef]

31. Papadakis, V.G. Effect of fly ash of Portland cement systems. Part I. Low-calcium fly ash. Cem. Concr. Res. 1999, 29, 1727-1736. [CrossRef]

32. Golewski, G.L. An analysis of fracture toughness in concrete with fly ash addition, considering all models of cracking. IOP Conf. Ser. Mater. Sci. Eng. 2018, 416, 012029. [CrossRef]

33. Siddique, R. Effect of fine aggregate replacement with Class F fly ash on the mechanical properties of concrete. Cem. Concr. Res. 2003, 33, 539-547. [CrossRef]

34. Sadowski, T.; Golewski, G.L. A failure analysis of concrete composites incorporating fly ash during torsional loading. Compos. Struct. 2018, 183, 527-535. [CrossRef] 
35. Dragas, J.; Tosic, N.; Ignatovic, S.; Marinkovic, S. Mechanical and time-dependent properties of high-volume fly ash concrete for structural use. Mag. Concr. Res. 2016, 68, 632-645. [CrossRef]

36. Golewski, G.L. Effect of curing time on the fracture toughness of fly ash concrete composites. Compos. Struct. 2018, 185, 105-112. [CrossRef]

37. Golewski, G.L.; Sadowski, T. Experimental investigation and numerical modeling fracture processes in fly ash concrete at early age. Solid State Phenom. 2012, 188, 158-163. [CrossRef]

38. Szelag, M. Development of cracking patterns in modified cement matrix with microsilica. Materials 2018, 11, 1928. [CrossRef]

39. Plank, J.; Sakai, E.; Miao, C.W.; Yu, C.; Hong, J.X. Chemical admixtures-Chemistry, applications and their impact on concrete microstructure and durability. Cem. Concr. Res. 2015, 78, 81-99. [CrossRef]

40. Sanchez, F.; Sobolev, K. Nanotechnology in concrete-A review. Constr. Build. Mater. 2010, 24, $2060-2071$. [CrossRef]

41. Sobolev, K.; Gutierrez, M.F. How nanotechnology can change the concrete world. Am. Cer. Soc. Bull. 2005, 10, 14-18.

42. Szostak, B.; Golewski, G.L. Effect of nano admixture of CSH on selected strength parameters of concrete including fly ash. IOP Conf. Ser. Mater. Sci. Eng. 2018, 416, 012105. [CrossRef]

43. Sadowski, L.; Hola, J.; Czarnecki, L.; Mathia, T.G. New paradigm in the metrology of concrete surface morphology: Methods, parameters and applications. Measurement 2020, 169, 108497. [CrossRef]

44. Zou, F.; Shen, K.; Hu, C.; Wang, F.; Yang, L.; Hu, S. Effect of sodium sulfate and C-S-H seeds on the reaction of fly ash with different amorphous alumina contents. ACS Sustain. Chem. Eng. 2020, 8, 1659-1670. [CrossRef]

45. Zhang, P.; Wan, J.; Wang, K.; Li, Q. Influence of nano-SiO2 on properties of fresh and hardened high performance concrete: A state of the art review. Constr. Build. Mater. 2017, 148, 648-658. [CrossRef]

46. Thomas, J.J.; Jennings, H.M.; Chen, J.J. Influence of Nucleation seeding on the hydration mechanisms of tricalcium silicate and cement. J. Phys. Chem. C 2009, 113, 4327-4334. [CrossRef]

47. Antonovic, V.; Pundiene, I.; Stpnys, R.; Cesniene, J.; Kariene, J. A review of the possible applications of nanotechnology in refractory concrete. J. Civ. Eng. Manag. 2010, 16, 595-602. [CrossRef]

48. John, E.; Matschei, T.; Stephan, D. Nucleation seeding with calcium silicate hydrate-A review. Cem. Concr. Res. 2018, 113, 74-85. [CrossRef]

49. Land, G.; Stephan, D. The effect of synthesis conditions on the efficiency of C-S-H seeds to accelerate cement hydration. Cem. Concr. Compos. 2018, 87, 73-78. [CrossRef]

50. Wang, B.; Yao, W.; Stephan, D. Preparation of calcium silicate hydrate seeds by means of mechanochemical method and its effect on the early hydration of cement. Adv. Mech. Eng. 2019, 11,1-7. [CrossRef]

51. Zou, F.; Hu, C.; Wang, F.; Ruan, Y.; Hu, S. Enhancement of early-age strength of the high content fly ash blended cement paste by sodium sulfate and C-S-H seeds towards a greener binder. J. Clean. Prod. 2020, 244, 118566. [CrossRef]

52. Wang, F.; Kong, X.; Jiang, L.; Wang, D. The acceleration mechanism of nano C-S-H particles on OPC hydration. Constr. Build. Mater. 2020, 249, 118734. [CrossRef]

53. Pużak, T. Nanotechnologia-Przyszłość prefabrykacji betonowej. Mater. Bud. 2010, 11, 16-18. (In Polish)

54. Li, H.; Sun, H.; Tian, J.; Yang, Q.; Wan, Q. Mechanical and ultraconic testing of self-compacting concrete. Energies 2019, 12, 2187. [CrossRef]

55. Li, H.; Sun, H.; Zhang, W.; Gou, H.; Yang, Q. Study on mechanical properties of self-compacting concrete and its filled in-line multi-cavity steel tube bundle shear wall. Energies 2019, 12, 3466. [CrossRef]

56. Jagadesh, P.; Ramachandra Murthy, A.; Murugesan, R. Effect of processed sugar cane bagasse ash on mechanical and fracture properties of blended mortar. Constr. Build. Mater. 2020, 262, 120846. [CrossRef]

57. Szelag, M. Mechano-physical properties and microstructure of carbon nanotube reinforced cement paste after thermal load. Nanomaterials 2017, 7, 267. [CrossRef]

58. Yang, X.; Li, S.; Huang, H.; Li, J.; Kobayashi, N. Effect of carbon nanoadditives on lithium hydroxide monohydrate-based composite materials for low temperature chemical heat storage. Energies 2017, 10, 644. [CrossRef]

59. Rahmani, E.; Kazem Sharbatdar, M.; Beygi, M.H.A. The effect of water -to-cement ratio on the fracture behaviors and ductility of Roller Compacted Concrete Pavement (RCCP). Theor. Appl. Fract. Mech. 2020, 109, 102753. [CrossRef]

60. EN 196-1:2016. Methods of Testing Cement. Determination of Strength; NSAI Standards: Dublin, Ireland, 2016. 
61. Salvador, R.P.; Cavalaro, S.H.P.; Segura, I.; Figueiredo, A.D.; Pérez, J. Early age hydration of cement pastes with alkaline and alkali-free accelerators for sprayed concrete. Constr. Build. Mater. 2016, 111, 386-398. [CrossRef]

62. Szostak, B.; Golewski, G.L. Modification of early strength parameters of concrete by the addition of fly ash and admixture of nano C-S-H for application in 3D printing. MATEC Web Conf. 2020, 323, 01016. [CrossRef]

63. Golewski, G.L. Effect of fly ash addition on the fracture toughness of plain concrete at third model of fracture. J. Civ. Eng. Manag. 2017, 23, 613-620. [CrossRef]

64. Zhou, S.; Zhang, Y.; Zhou, D.; Wang, W.; Li, D.; Ke, Z. Experimental study on mechanical properties of fly ash stabilized with cement. Adv. Civ. Eng. 2020, 2020, 6410246.

65. Golewski, G.L.; Sadowski, T. Macroscopic evaluation of fracture processes in fly ash concrete. Solid State Phenom. 2016, 254, 188-193. [CrossRef]

66. Golewski, G.L. Estimation of the optimum content of fly ash in concrete composite based on the analysis of fracture toughness tests using various measuring systems. Constr. Build. Mater. 2019, 213, $142-155$. [CrossRef]

Publisher's Note: MDPI stays neutral with regard to jurisdictional claims in published maps and institutional affiliations.

(C) 2020 by the authors. Licensee MDPI, Basel, Switzerland. This article is an open access article distributed under the terms and conditions of the Creative Commons Attribution (CC BY) license (http://creativecommons.org/licenses/by/4.0/). 